\title{
The effectiveness of jigsaw learning strategy to teach speaking
}

\author{
Urip Widodo and Mugiyo \\ STABN Raden Wijaya, Indonesia
}

\begin{abstract}
This research aims to know whether the jigsaw learning strategy is better than the audio-lingual method to teach speaking. This experimental research was carried out in the vocational school. The population was four classes (140 students) of eleventh grade A, B, C, D, and E. The samples were the eleventh grade $\mathrm{A}$ as the experimental group and $\mathrm{B}$ as the control group. Each group consists of 30 students. The experimental group was taught using the Jigsaw learning strategy, while the control group used the Audio-Lingual Method. The data collection technique was through the speaking test, and the data analysis technique was through descriptive statistics and inferential statistics. The data analysis shows that the mean score of the students who were taught by using the jigsaw learning strategy is 81,23 , while the mean score of the students who were taught by using the audio-lingual method is 76,03 . Moreover, the Fo $(8,77)$ is higher than Ft $(4,00)$ at the significance level of significance $a=$ 0,05 , which means the null hypotheses are rejected, and the alternative hypotheses are accepted. In conclusion, the jigsaw learning strategy is more effective than the audio-lingual method to teach speaking.
\end{abstract}

\section{ARTICLE HISTORY}

Received November 24, 2021

Accepted December 17, 2021

Published December 31, 2021

\section{KEYWORDS:}

ALM, Experiment, Jigsaw,

Speaking.

\section{Introduction}

In this age of globalization, English has increasingly become the medium in every communication domain, both in local and global contexts (Fajrina, 2015). English is widely used in Indonesia as a language of international communication. In this sense, spoken English has its patterns that give meaning to daily communication (Fata, 2014). It is extensively taught from the primary up to the tertiary level of education. It is the act of anticipation that this country will face more competition with the trend of globalization than before. For instance, Indonesia must be ready to face the ASEAN Economic Society. ASEAN Economic Society will bring lots of demands to ASEAN society, including Indonesia. One of the demands is mastering the English language, and one of the English skills that have to be mastered is speaking skill. It is very important because by mastering speaking skills, people will communicate with others.

There are four skills in English, namely speaking, listening, writing, and reading. As one of English skills, speaking has to be mastered by everyone, especially the students. Speaking skill is the skill that will help students to interact or to communicate with others. On the next level, speaking skill is very useful for the students when they have an interview on applying the occupation. As a skill, speaking is the most used skill by people rather than the three other skills. Speaking will give more benefits for learners, especially for vocational school students. It can be known from the fact that most companies or offices look for very competent and knowledgeable people in their field. To deliver everything they know, people should use their capability to speak online job interviews. For the students of a vocational school who want to get a job, a job interview is a golden opportunity to be reached if they can speak fluently and clearly. In the job interview, they can inform what they know 
about the job description, present what they learned in vocational school, and persuade the interviewer. Those make the applicant can be accepted easily to work in the company.

Moreover, mastering English, especially speaking skills, will be very useful after they are accepted into the company. Although usually, foreign language (FL) learners aim for communicativeness and fluency, many try to reach the highest levels in all aspects, native-like pronunciation being one of them (Baran-Lucartz, 2020). The English language can be used as a daily conversation in the company; besides, it will also be used to communicate with the leaders. It shows that the demands of mastering English speaking skills for the students, especially vocational school students, are as the requirements, it is not just a skill that has to be mastered when they study in the school but also a need for the students must have. Consequently, lacking communicative competence, the opportunity to interact in the target language, the motivation to learn, and the appropriate learning environment represent major challenges that face EFL classes (Alsyouf, 2021).

The teaching method that the teacher uses is often assumed as the factor that causes the student's speaking problem. The current standard of English speaking proficiency among students does not reflect sufficient teaching and learning of speaking components (Tuspekova et al., 2020). There are lots of methods to encourage students' speaking ability communicatively. This research proposes a jigsaw learning strategy compared to the audio-lingual method to encourage students' speaking ability. Jigsaw learning strategy is a kind of learning strategy that focuses on students' activity (students-center learning). Jigsaw learning strategi possibilities students to be more active in the class. Students have to work in small groups. It pushes them to speak a lot. With this method, all students can independently search for knowledge and share knowledge with classmates (Fitriyah \& Fauzi, 2020).

Researchers have conducted several previous studies about jigsaw learning strategies. Jigsaw learning strategy affords to improve scholars' English speaking ability and scholars' skill in Arabic translation (Fitriyah \& Fauzi, 2020; Ubaedillah, 2019). Moreover, jigsaw learning strategy also improves scholars' critical thinking skills and scholars' ability to design lesson plans (Saguni, 2013; Saputra et al., 2019). However, all of those studies focus on the scholars' subject. A certain study is needed about how jigsaw learning strategy will affect students' skills because surely it is different among scholars and students. This is the gap that is completed through this study. This study examines whether a jigsaw learning strategy is more effective than ALM to teach speaking for vocational school students.

Based on the preliminary study at the vocational school, it is assumed that the teacher uses the Audio Lingual Method. It could be seen from several teaching techniques implemented in classroom teaching. The teacher often implements drill techniques in teaching speaking material before practicing the dialogue; he also asks the students to memorize the dialogue and then perform it in front of the class. The teacher almost always uses the target language or English language during the lesson. Even the teacher asks the students to always use the English language in the class, and the students will get a little punishment if they use Indonesian or Javanese language. Even though teachers need to correct students' errors during their speaking practices, it is essential that they also consider the students' needs (Fitriani et al., 2019). Besides, sometimes the teacher asks the students to read the passage or dialog loudly; after that, the teacher will give some corrections if the students make mistakes. The teacher also often says to neglect the grammar or structure. As an evaluation, usually, the teacher does a conversation practice with the students; surely, the conversation is totally in English or the target language. The teacher seems to be the role of the teaching-learning process, and the students just receive what the teacher taught.

As a result, the students are inactive in the class. They can not convey their interpretation of the material. The students also can not enjoy the class it is because they just follow what the teacher said or taught. Moreover, most of the students had many difficulties following the teaching and learning process. It is because they lack interest and motivation and lack skill either in the vocabulary or in the speaking skill. Most of the students look bored in following the teaching and learning process, and they become passive in the class. Surely it much influences their speaking ability. The students can not speak well if they have already been bored and even angry with the class teacher. Maybe the teacher expects that implementing Audio Lingual Method and pushing them to use the English language totally in the class will help the students speak well, but the reality is different because the condition of each student is different. That is why this research proposes a method that will be used to teach speaking, which hopefully can be useful, and the method is a jigsaw learning strategy. 


\section{Literature Review}

According to (Florez \& Howartz, 2001), speaking is a two-way process involving a true communication of ideas, information, or feelings. Speaking is obviously important as a means of communication because generally,, people communicate by using oral language. Moreover, speaking is an interactive process constructing meaning that involves producing, receiving, and processing information (Louma, 2004). Speaking is considered a successful and effective means of communication when one can perform everything that must be involved in speaking, such as ideas, what to say, language, how to use vocabulary, grammar, and pronunciation. In teaching, the whole language and meaningful context must be emphasized rather than details (Brown, 2001). The explanation needs a learning strategy to teach speaking that focuses on communication and collaboration. In this case, two teaching methods were examined, namely jigsaw learning strategy, a kind of collaborative learning, and ALM, a kind of communicative learning.

Most people say that testing speaking is the most complex to assess with precision. Many teachers often feel uncomfortable when handling speaking tests since it is often difficult to be objective and consistent when testing a large number of students. But it does not mean that the speaking test can not be measured correctly. In this paper, the writer quoted the one Harris uses as it is the most applicable to the speaking class rating system. Harris, as quoted by (Wijarwadi 2008), explains that five components are generally recognized in analyses of speech process that are pronunciation, grammar, vocabulary, fluency (the ease and speed of the flow of the speech), and comprehension.

According to (Isgiarno et al., 2020) the jigsaw is an activity that creates interaction by providing students with an opportunity to help each other build comprehension actively. By using the jigsaw, students are encouraged to communicate and accomplish the idea of the task given by the teacher, together with their group members actively. Students meet with members from the other groups who are assigned the same aspect, and after mastering the material, return to the homegroup to teach the material to their group members. Moreover, the jigsaw technique is one of the cooperative learning techniques that have been used in language teaching and learning. This strategy is efficient teaching material that also encourages speaking, engagement, interaction, teaching, and cooperation by giving each member of the group an essential part to play in the academic activity (Hadisantosa, 2017).

First of all, the organization in the jigsaw activities should work in the expert groups. In these groups, students work in the same group of four to six members, and each member in a team becomes an expert on a topic. After mastering the material and sharing the information, the students present and teach the new group. Then, each student tells the other group member about the topic. After information-sharing and discussion, the groups have an opportunity to review the material before taking a quiz (Kessler, 2015).

Meanwhile, ALM is the classical and operant conditioning model providing the perfect foundation for mimicry drills and pattern practices (Brown, 2004). Meanwhile, (Freeman 2000) stated that ALM is a method that drills students in grammatical sentence patterns. The ALM considered language simply as a form of behavior to be learned through the information of correct speech habits (S Thornburry, 2000). The procedure that teachers should adopt in implementing ALM, as stated by (Richards \& Rodgers, 2001), is that the lesson begins with the modeling of the speaking material by the teacher, and the students follow what the teacher said. Then, the students repeat each line of the dialogue, individually and in chorus. Next, the students produce dialogue, and the teacher pays attention to pronunciation, intonation, and fluency. If there is any mistake, the teacher needs to immediately correct the mistakes. Then, the students memorize the dialogue gradually and line by line. After they have memorized it, the dialogue is read aloud in chorus, one half saying one speaker and the other half responding. The students are really not allowed to open their book or read the dialogue throughout this phase.

After that, to make the learning process more interesting and effective, the dialogue is adapted to the students' interests or situations by changing certain keywords or phrases. Students act out this phase. The teacher may select certain key structures or sentences from the dialogue and use as the basis for pattern drills of different kinds. The selection is based on the current speaking material learned in class. Then, these are practiced in chorus and individually. After all this process, the students should memorize certain key sentences or structures from the dialogue. Then, the last process of speaking activity is that the teacher divides the student into a group of two and asks them to practice all the dialogue from the textbook in front of the class. 
Principally, this research examined two teaching approaches: collaborative and communicative. Collaborative teaching methods such as CTL and PBL have improved students' speaking skills (Haerani \& Jatiraga, 2019; Rahmah, 2018; Widodo, 2020). Meanwhile, communicative teaching methods such as the pow-tega technique, show and tell, and think aloud have been used to improve students' speaking and reading skills (Bangun, 2018; Wahyuni, 2018; Yusuf et al. 2018). However, no specific study tries to examine these two teaching methods, namely jigsaw, and ALM, to teach speaking. Jigsaw teaching method, which is categorized into collaborative teaching method is claimed an effective way to teach speaking; on the other hand,, ALM represents communicative teaching method is claimed as well as an appropriate method to teach speaking. Based on those explanations, this study examined which one is better to teach speaking, jigsaw or ALM, as both are claimed to be effective teaching methods to teach speaking.

\section{Method}

This research was carried out from March to May 2021. The research was a post-test-only experimental research design. In a post-only experimental research design, the test is conducted just once after the treatment (Sugiyono, 2016). It is to know the effect of the teaching methods both in experimental class and in control class implemented. The research design is as follows:

Table 1. Research Design

\begin{tabular}{llll}
\hline \multicolumn{1}{c}{ Group } & \multicolumn{1}{c}{ Intervention } & Post Test \\
\hline Experimental Class & Taught by using Jigsaw & $\mathrm{O}_{1}$ & \\
\hline Control Class & Taught by using ALM & $\mathrm{O}_{2}$ & \\
\hline
\end{tabular}

The researcher examines the influence of jigsaw learning strategy on students' speaking skills are two groups in this Experiment, namely the experimental and control groups. The experimental group is the class that was taught by using the Jigsaw learning strategy, and the control group is the class that was taught by using the Audio-Lingual Method. They were given different treatments. After the treatment, the groups were given a post-test. The population is 140 students. The population is presented as follows:

Table 2. Number of Population

\begin{tabular}{|c|c|c|c|c|}
\hline Class & Number of Students & Control Class & Experimental Class & Total \\
\hline A & 30 & & $\sqrt{ }$ & \multirow{2}{*}{$\begin{array}{c}\text { Sampel: } \\
60 \\
\text { students }\end{array}$} \\
\hline B & 30 & $\sqrt{ }$ & & \\
\hline $\mathrm{C}$ & 27 & & & \\
\hline $\mathrm{D}$ & 28 & & & \\
\hline $\mathrm{E}$ & 25 & & & \\
\hline Total & 140 & & & \\
\hline
\end{tabular}

Meanwhile, the samples of the research were the eleventh grade A students as the experimental class and the eleventh grade B students as the control class. Each class consists of 30 students. The type of sampling which was used is cluster random sampling. The sampling and decision of experiment and control classes were made by lottery. Speaking test is a technique to be used in collecting the data. It uses two examiners, namely the researcher and an English teacher, to avoid bias. The data are analyzed through statistical descriptive and inferential.

Normality and homogeneity tests were used before testing the hypothesis. Moreover, the statistical device that is appropriate is the analysis of variance (ANOVA). The researcher uses one dependent variable and one independent variable; dealing with this research, the dependent variable is students' speaking skills, and the independent variable is teaching methods. Hypothesis null $\left(\mathrm{H}_{\mathrm{o}}\right)$ is rejected if $F_{o}>F_{t}$ at the level of significance $a=0,05$, and vice versa. It is known that the $F_{t}$ is 4.00 . 


\section{Result and Discussion}

\section{The data of speaking test students Taught by Jigsaw Learning Strategy}

The data are obtained through a speaking test. The test is conducted once with two examiners. The data of speaking test students taught by using jigsaw are: 69, 69, 71, 72, 72, 73, 75, 76, 77, $77,78,79,79,79,83,83,83,83,83,85,85,85,86,88,88,88,88,93,95,95$. The data description can be seen as follows:

Table 3. The frequency distribution of data

\begin{tabular}{lllllll}
\hline $\begin{array}{l}\text { Class } \\
\text { Limit }\end{array}$ & $\begin{array}{l}\text { Class } \\
\text { Boundaries }\end{array}$ & $\begin{array}{l}\text { Frequency } \\
\text { (fi) }\end{array}$ & $\begin{array}{l}\text { Midpoint } \\
\text { (Xi) }\end{array}$ & $\mathbf{X}^{\mathbf{2}}$ & Fixi & fixi $^{2}$ \\
\hline $66-70$ & $65,5-70,5$ & 2 & 68 & 4624 & 136 & 9248 \\
\hline $71-75$ & $70,5-75,5$ & 5 & 73 & 5329 & 365 & 26645 \\
\hline $76-80$ & $75,5-80,5$ & 7 & 78 & 6084 & 546 & 42588 \\
\hline $81-85$ & $80,5-85,5$ & 8 & 83 & 6889 & 664 & 55112 \\
\hline $86-90$ & $85,5-90,5$ & 5 & 88 & 7744 & 440 & 38720 \\
\hline $91-95$ & $90,5-95,5$ & 3 & 93 & 8649 & 279 & 25947 \\
\hline$\sum$ & & $\mathbf{3 0}$ & & $\mathbf{3 9 3 1 9}$ & $\mathbf{2 4 4 0}$ & $\mathbf{1 9 8 2 6 0}$ \\
\hline
\end{tabular}

Mean $=81,23$, Median $=83, \mathrm{SD}=7,31$, Mode $=83$

The table of the distribution of data shows that the mean of the students' speaking score is 81,23 , the mode is 83 , the standard deviation is 7,31 , and the median is 83 . Moreover, the frequency distribution of students' speaking skills is described in the histogram and polygon below:

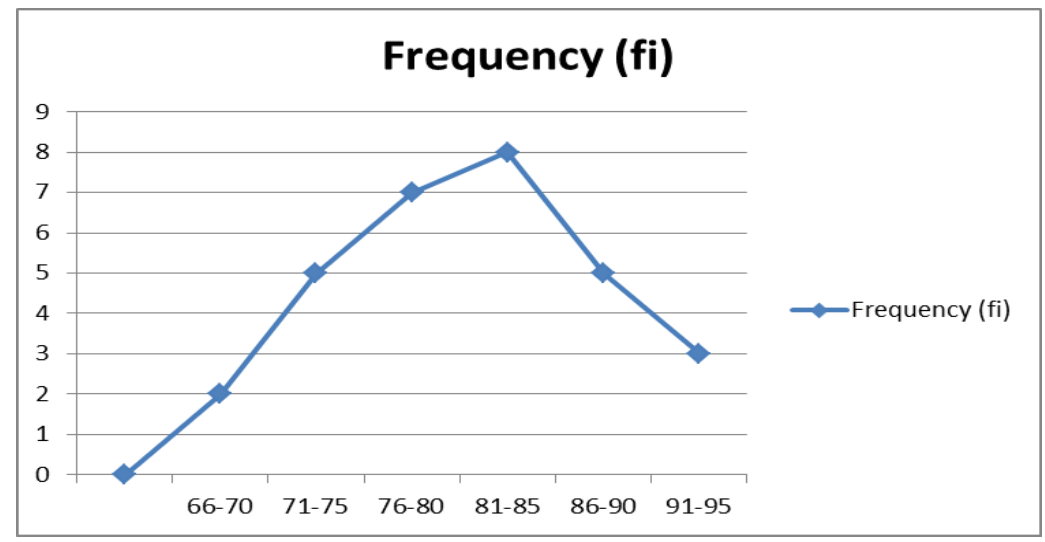

Figure 1. Histogram and Polygon of Data Taught by Using Jigsaw

\section{The data of students' speaking test taught by using Audio-Lingual Method}

The students' score are: $63,67,67,67,68,68,71,71,73,73,73,73,78,78,78,78,78,78,79$, $79,79,79,79,80,80,83,83,85,85,88$. The data description can be seen as follows: 
Table 5. The frequency distribution of data

\begin{tabular}{lllllll}
$\begin{array}{l}\text { Class } \\
\text { Limit }\end{array}$ & $\begin{array}{l}\text { Class } \\
\text { Boundaries }\end{array}$ & $\begin{array}{l}\text { Frequency } \\
\text { (fi) }\end{array}$ & $\begin{array}{l}\text { Midpoint } \\
\text { (Xi) }\end{array}$ & $\mathbf{X}^{\mathbf{2}}$ & fixi & fixi $^{\mathbf{2}}$ \\
\hline $61-65$ & $60,5-65,5$ & 1 & 63 & 3969 & 63 & 3969 \\
\hline $66-70$ & $65,5-70,5$ & 5 & 68 & 4624 & 340 & 23120 \\
\hline $71-75$ & $70,5-75,5$ & 6 & 73 & 5329 & 438 & 31974 \\
\hline $76-80$ & $75,5-80,5$ & 13 & 78 & 6084 & 1014 & 79092 \\
\hline $81-85$ & $80,5-85,5$ & 4 & 83 & 6889 & 332 & 27556 \\
\hline $86-90$ & $85,5-90,5$ & 1 & 88 & 7744 & 88 & 7744 \\
\hline$\sum$ & & $\mathbf{3 0}$ & & $\mathbf{3 4 6 3 9}$ & $\mathbf{2 2 7 5}$ & $\mathbf{1 7 3 4 5 5}$ \\
\hline
\end{tabular}

Mean $=76,03$, Median $=78, \mathrm{SD}=6,24$, Mode $=78$

The table of the distribution of data shows that the mean of the students' speaking score is 76,03 , the mode is 78 , the standard deviation is 6,24 , and the median is 78 . Moreover, the frequency distribution of students' speaking skills is described in the histogram and polygon below:

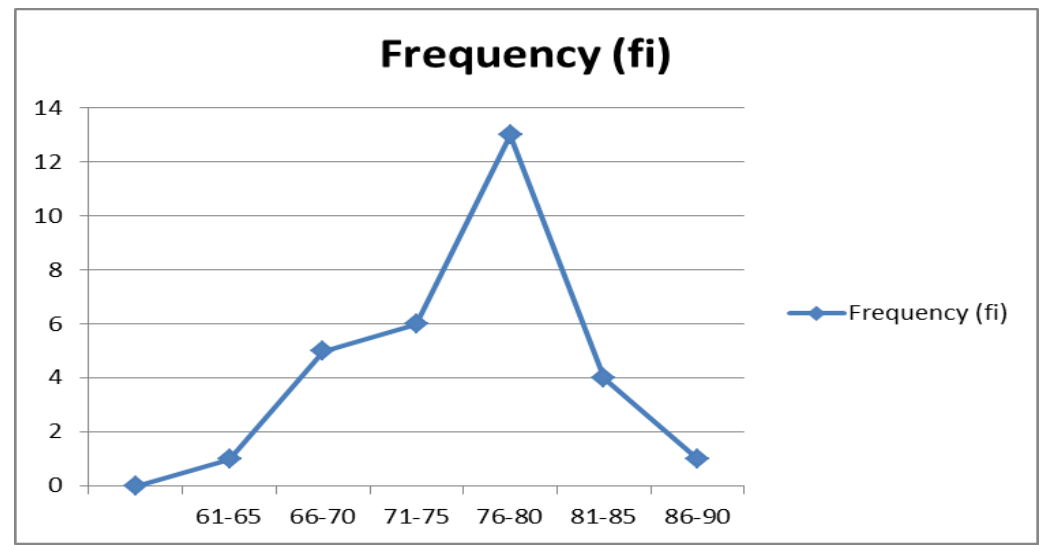

Figure 2. Histogram and Polygon Data Students Taught by Using ALM

\section{Normality Test}

Normality test of the scores of students speaking test taught by using the jigsaw. Normality test is a pre-requisite test before conducting the Anova test. Normality test in this research is by using test. The data are categorized in normal distribution if $\mathrm{L}_{\mathrm{o}}$ is lower than $\mathrm{L}_{\mathrm{t}}\left(\mathrm{L}_{0}<\mathrm{L}_{\mathrm{t}}\right)$. The steps of analysis is presented as follows:

Table 6. Normality Test students' speaking score taught using Jigsaw

\begin{tabular}{|c|c|c|c|c|c|}
\hline $\mathbf{X}$ & $\mathbf{f}$ & $\mathbf{Z}$ & $\mathbf{f}_{\mathbf{z}}$ & $\mathbf{s}_{\mathbf{z}}$ & $\mathbf{f}_{\mathbf{z}}-\mathbf{s}_{\mathbf{z}}$ \\
\hline 69 & 2 & $-1,67258$ & 0,047205 & 0,066667 & 0,019462 \\
\hline 71 & 1 & $-1,39913$ & 0,080887 & 0,1 & 0,019113 \\
\hline 72 & 2 & $-1,26241$ & 0,103401 & 0,166667 & 0,063266 \\
\hline 73 & 1 & $-1,12569$ & 0,130149 & 0,2 & 0,069851 \\
\hline 75 & 1 & $-0,85224$ & 0,19704 & 0,233333 & 0,036293 \\
\hline 76 & 1 & $-0,71552$ & 0,237145 & 0,266667 & 0,029522 \\
\hline 77 & 2 & $-0,57879$ & 0,281364 & 0,333333 & 0,051969 \\
\hline 78 & 1 & $-0,44207$ & 0,329219 & 0,366667 & 0,037448 \\
\hline
\end{tabular}




\begin{tabular}{|l|l|c|c|c|c|}
79 & 3 & $-0,30535$ & 0,38005 & 0,466667 & 0,086616 \\
\hline 83 & 5 & 0,241544 & 0,595433 & 0,633333 & 0,0379 \\
\hline 85 & 3 & 0,51499 & 0,69672 & 0,733333 & 0,036613 \\
\hline 86 & 1 & 0,651713 & 0,742707 & 0,766667 & 0,02396 \\
\hline 88 & 4 & 0,925159 & 0,822558 & 0,9 & 0,077442 \\
\hline 93 & 1 & 1,608775 & 0,946167 & 0,933333 & 0,012834 \\
\hline 95 & 2 & 1,882221 & 0,970097 & 1 & 0,029903 \\
\hline
\end{tabular}

Based on the computation of the students' score taught by using the jigsaw, the highest score of $\mathrm{L}_{\mathrm{o}}$ (L obtained) is 0.086 . From the table of the critical value of lilies test with the students' number $(\mathrm{n})=30$ at the significance level $\mathrm{a}=0.05$, the score of $\mathrm{L}_{\mathrm{t}}$ is 0.161 . As $\mathrm{L}_{\mathrm{o}}$ is lower than $\mathrm{L}_{\mathrm{t}}(0.086)<$ (0.161), it can be concluded that the data are in the normal distribution. Based on the result of the students' speaking test. A normality test is needed to know whether the data are in the normal distribution or not. The analysis of normality is presented as follows:

Tabe1 7. Normality test of the students speaking test taught by using ALM

\begin{tabular}{cccccc}
\hline $\mathbf{X}$ & $\mathbf{F}$ & $\mathbf{Z}$ & $\mathbf{f}_{\mathbf{z}}$ & $\mathbf{s}_{\mathbf{z}}$ & $\mathbf{f}_{\mathbf{z}}-\mathbf{s}_{\mathbf{z}}$ \\
\hline 63 & 1 & $-2,08703$ & 0,018443 & 0,033333 & 0,014891 \\
\hline 67 & 3 & $-1,44651$ & 0,074017 & 0,133333 & 0,059317 \\
\hline 68 & 2 & $-1,28638$ & 0,099155 & 0,2 & 0,100845 \\
\hline 71 & 2 & $-0,80599$ & 0,210124 & 0,266667 & 0,056542 \\
\hline 73 & 4 & $-0,48573$ & 0,31358 & 0,4 & 0,08642 \\
\hline 78 & 6 & 0,314923 & 0,62359 & 0,6 & 0,02359 \\
\hline 79 & 5 & 0,475054 & 0,682626 & 0,766667 & 0,084041 \\
\hline 80 & 2 & 0,635184 & 0,737346 & 0,833333 & 0,095987 \\
\hline 83 & 2 & 1,115576 & 0,867698 & 0,9 & 0,032302 \\
\hline 88 & 2 & 1,435837 & 0,924476 & 0,966667 & 0,042191 \\
\hline
\end{tabular}

Based on the computation of students' speaking scores taught using ALM, Lo's highest score (L obtained) is 0.100 . From the table of the critical value of liliefors test with the students' number $(\mathrm{n})=30$ at the significance level $\mathrm{a}=0.05$, the score of $\mathrm{L}_{\mathrm{t}}$ is 0.161 . As $\mathrm{L}_{\mathrm{o}}$ is lower than $\mathrm{L}_{\mathrm{t}}(0.100)<$ (0.161), it can be concluded that the data are in the normal distribution.

\section{Homogeneity Test}

Besides the normality test, the homogeneity test as the pre-requisite test is also needed before conducting the ANOVA test. A homogeneity test is conducted to know whether the data are homogeneous or not. The data are homogeneous if $\mathrm{x}_{0}^{2}$ is lower than $\mathrm{xt}_{\mathrm{t}}{ }^{2}$. The chi-square table for degree of freedom $(\mathrm{df})=1$ at the level of significance $a=0.05$ is 1,86 . Based on the data analysis, the result is as follow: 
F-Test Two-Sample for Variances

\begin{tabular}{lll}
\hline & Jigsaw & ALM \\
\hline Mean & 81,23333333 & 76,03333333 \\
Variance & 53,4954023 & 38,99885057 \\
Observations & 30 & 30 \\
Df & 29 & 29 \\
F & 1,37171741 & \\
P(F $<=$ f) one-tail & 0,199895987 & \\
F Critical one-tail & 1,860811435 & \\
\hline
\end{tabular}

Based on the data analysis above, it can be seen that the $\mathrm{x}_{0}^{2}$ score is 1,33 lower than $\mathrm{x}_{\mathrm{t}}{ }^{2}(1,86)$, so it can be concluded that the data are homogeneous.

\section{Anova}

After the requirements of data testing are done, the data are then analyzed by using single-factor ANOVA. The result of the single factor ANOVA test is as follow:

\begin{tabular}{|c|c|c|c|c|c|c|}
\hline Source of Variation & $S S$ & $D f$ & $M S$ & $F$ & P-value & $F$ crit \\
\hline Between Groups & 405,6 & 1 & 405,6 & 8,770275 & 0,004431 & 4,006873 \\
\hline Within Groups & 2682,333 & 58 & 46,24713 & & & \\
\hline Total & 3087,933 & 59 & & & & \\
\hline
\end{tabular}

Based on the analysis above, the Fo is 8,77 while the Ft is 4,00 . Moreover, the P-value is 0,004 lower than the significance level of 0,05 , so it can be concluded that the null hypothesis is rejected and the alternative hypotheses are accepted, which means the jigsaw learning strategy is more effective to teach speaking than the audio-lingual method.

\section{Discussion}

The jigsaw learning strategy is basically wished to afford to improve students' learning achievement. Students' learning achievements are expected to increase when they are learning using cooperative learning, especially the jigsaw strategy (Effendi-hasibuan et al., 2020). Jigsaw learning strategy demands students to speak, starting from speaking in small groups to the whole class or in front of the class. This activity makes students become more active in the class. This learning model emphasizes students' activity during the teaching and learning process, and students are expected to be more active in getting knowledge (Edriati et al., 2015). The students should push themselves to speak and to talk. Besides, by using a jigsaw learning strategy, the students can create their own idea related to the topic of the material. Students have to discuss the topic with their classmates, and they have to deliver their idea by speaking. The advantages of the jigsaw learning strategy are exercising students to speak, discuss, and understand the material concept (Sukarta \& Gunamantha, 2012).

Meanwhile, in ALM, teachers have more roles than the students. The teacher controls the class. It is in line with what is said by Widodo (2020) that ALM is a kind of traditional teaching method in which the teacher has great power, which means that the class is controlled by the teacher or teacher center class. The students just received what the teacher instructed. The learning activities in this method make students lack opportunities to improve their speaking skills.

Moreover, Mart (2013) states that ALM aims to develop students' communicative competence by using dialogues and drills. In this case, the teacher will read the dialogue, and the 
students will repeat it. The Students' role is just repeating and revising the incorrect utterance. Students have to follow teachers' instructions. It cages students' ideas and creativity. Besides, students that are taught using ALM will not be able to speak in real communication outside the classroom. Therefore, it ignores the communicative competence in teaching practice (Liu \& Shi, 2007).

Jigsaw learning strategy is better to teach speaking compared to ALM. In the jigsaw learning strategy, the students have more time to explore their ability to speak; meanwhile, in ALM, the students have to obey the teachers' instructions. By using ALM, students just practice what the teacher said. The word practice means that something is always repeated, but in any case, between the first learning situation and the real learning situation, it will try to practice students' skills (Aprianto et al., 2020). The jigsaw learning strategy needs discussion activity either in small or large groups. This activity makes the teaching and learning process more attractive. Using a jigsaw cooperative learning in teaching and learning activities makes the students' attention is more focused, and they can express the ideas they had in mind. For shy students, using the jigsaw cooperative learning will automatically respond to all assigned tasks, so they will issue their opinions more actively, and they can also listen to the opinion of their friends and respond to it immediately (Marhamah \& Mulyadi, 2013). Students have an important role in the class, while teachers just function as facilitators to observe and evaluate the successful discussion stage. In ALM, teachers conduct all activities. Teachers read, and the students just repeat, teachers revise, and the students just follow. Basically, ALM is designed for students who have good listening skills. The theory is that a good listener will ultimately make a better speaker because learners must focus their attention on actually hearing what is said. Only then will they be able to internalize such linguistic features as pronunciation and intonation; thus, making them more effective speakers (Rahman \& Melhim, 2009). Students are passive while teachers more active in directing the class.

\section{Conclusion}

Jigsaw learning strategy is more effective than ALM in teaching vocational students speaking. Therefore, the teacher should implement a collaborative teaching method to teach speaking because students tend to speak much when they have to associate and work with their friends. However, students' psychological aspects such as students' anxiety, students' confidence, or students' learning interest are not evaluated in this study. It will be better if further study researches the effect of students' psychological aspects on students' speaking skills. It needs further study to compare jigsaw learning strategy with another collaborative learning strategy in teaching another skill of English such as reading, writing, or listening.

\section{References}

Alsyouf, A., \& Al Kayed, M. (2021). Interactive intervention strategy for English as a foreign language classes versus traditional methods to teach speaking. Studies in English Language and Education, 8(2), 479-491.

Aprianto, A., Ritonga, M., Marlius, Y., \& Nusyur, R. (2020). The Influence of Using Audio-lingual Method on Students' Speaking Skill in Madrasah Diniyah Takmiliyah Awwaliyyah. Izdihar: Journal of Arabic Language Teaching, Linguistics, and Literature, 3(2), 147-160. https://doi.org/10.22219/iiz.v3i2.12514

Bangun, B. K. (2018). Improving Students' Speaking Skill By Using Show And Tell Method: A Classroom Action Research. International Journal of Language Teaching and Education, 2(1), 41-48. https://doi.org/10.22437/ijolte.v2i1.4517

Baran-Lucartz, M. (2020). Ego boundaries and attainments in FL pronunciation. Studies in Second Language Learning and Teaching, 2(1), 45-66.

Brown, H. D. (2001). Teaching by Principles: An Interactive Approach to Language Pedagogy (2nd ed.). Longman Inc.

Brown, H. D. (2004). Principles of Language Learning and Teaching. Longman.

Edriati, S., Anggraini, V., \& Siska, M. (2015). Efektivitas model jigsaw disertai penilaian diskusi ntuk meningkatkan kemampuan matematis mahasiswa [The effectiveness of the jigsaw model 
with assessment discussion to improve student's mathematics ability]. Cakrawala Pendidikan, 2, 288-295.

Effendi-hasibuan, M. H., Dewi, F., Sulistiyo, U., \& Hindarti, S. (2020). Jigsaw Learning Strategy In A Diverse Science-Classroom Setting: Feasibility, Challenges, And Adjustment. Cakrawala Pendidikan, 39(3), 733-745. https://doi.org/10.21831/cp.v39i3.30634

Gani, S. A., Fajrina, D., \& Hanifa, R. (2015). Students' learning strategies for developing speaking ability. Studies in English Language and Education, 2(1), 16-28.

Fata, I. A. (2014). Is my stress right or wrong? Studying the production of stress by non-native speaking teachers of English. Studies in English Language and Education, 1(1), 59. https://doi.org/10.24815/siele.v1i1.1120

Fitriani, N., \& Zulkarnain, S. I. (2019). Vocational college students' common errors in EFL speaking performance. Studies in English Language and Education, 6(1), 141-151.

Fitriyah, T., \& Fauzi, M. F. (2020). Improving Quality of Arabic Translation Course through Jigsaw Cooperative Learning. Izdihar: Journal of Arabic Language Teaching, Linguistics, and Literature, 3(1), 17-30. https://doi.org/10.22219/jiz.v3i1.11033

Florez, M. A., \& Howartz. (2001). Improving Adult English Language Learners' Speaking Skills (ERIC Document Reproduction Service No. ED: 435204).

Freeman, L. (2000). Techniques and Principles in Language Teaching. Oxford University Press.

Hadisantosa, N. (2017). Using Jigsaw as a Cooperative Learning Technique in the University Level. Atmajaya University Press.

Haerani, R., \& Jatiraga, R. (2019). The Implementation of Project-Based Learning To Improve Student'S Speaking Skill. PROJECT (Professional Journal of English Education), 2(3), 270. https://doi.org/10.22460/project.v2i3.p270-274

Isgiarno, Y. C., Cahyono, B. Y., \& Rahmaningtyas, H. (2020). Increasing EFL Students' Writing Skill Using Jigsaw and Online Searching Strategy. IJEE (Indonesian Journal of English Education), 7(1), 97-110. https://doi.org/10.15408/ijee.v7i1.16383

Kessler, C. (2015). Cooperative Language Learning. Prentice-Hall.

Liu, Q. X., \& Shi, J. F. (2007). An Analysis of Language Teaching Approaches and Methods-Effectiveness and Weakness. Online Submission, 4(1), 69-71.

Louma, S. (2004). Assessing Speaking. Cambridge University Press.

Marhamah, M., \& Mulyadi, M. (2013). Jigsaw Cooperative Learning: A Viable Teaching-Learning Strategy? Journal of Educational and Social Research, 3(7), 710-715. https://doi.org/10.5901/jesr.2013.v3n7p710

Mart, C. T. (2013). The Audio-Lingual Method: An Easy Way of Achieving Speech. International Journal of Academic Research in Business and Social Sciences, 12(3), 121-132.

Rahmah, R. R. (2018). The Implementation of CTL Approach in Teaching Speaking at College Students Akademi Kebidanan Keluarga Bunda Jambi. International Journal of Language Teaching and Education, 2(1), 60-70. https://doi.org/10.22437/ijolte.v2i1.4617

Rahman, A., \& Melhim, A. (2009). Re-evaluating the Effectiveness of the Audio-lingual Method in Teaching English to Speakers of Other Languages. International Forum of Teaching and Studies, 5(2), 39-45.

Richards, J. J., \& Rodgers, T. (2001). Approaches and methods in language teaching (2nd ed.). Cambridge University Press.

S Thornburry. (2000). How to teach grammar. Longman.

Saguni, F. (2013). the Effectiveness of the Problem-Based Learning, the Jigsaw Type Cooperative Learning, and Lecturing Methods As Problem Solving. Cakrawala Pendidikan, 207-219.

Saputra, M. D., Joyoatmojo, S., Wardani, D. K., \& Sangka, K. B. (2019). Developing criticalthinking skills through the collaboration of Jigsaw model with problem-based learning model. International Journal of Instruction, 12(1), 1077-1094. https://doi.org/10.29333/iji.2019.12169a

Sugiyono, H. (2016). Metode kualitatif dan kuantitatif (23.ed) [Qualitative and quantitative methods (23.ed)]. Alfabeta, Bandung.

Sukarta, I. N., \& Gunamantha, I. M. (2012). PEMBELAJARAN KOOPERATIF TIPE JIGSAW DALAM MATA KULIAH TEKNOLOGI AIR DAN PENGOLAHAN LIMBAH INDUSTRI [JIGSAW TYPE COOPERATIVE LEARNING IN WATER TECHNOLOGY AND INDUSTRIAL WASTE TREATMENT COURSES]. Cakrawala Pendidikan, 31(1), 129-142. 
Tuspekova, A., Mustaffa, R., \& Ismail, K. (2020). Understanding English Speaking Practice in Public Schools in Kazakhstan: A Case Study in Almaty. 3L, Language, Linguistics, Literature, 26(1).

Ubaedillah, U. (2019). Improving Students' English Speaking Ability Through Jigsaw. Research and Innovation in Language Learning, 2(3), 216-227. https://doi.org/10.33603/rill.v2i3.2127

Wahyuni, S. (2018). Increasing Speaking Achievement by Using Pow-Tega Teachnique. International Journal of Language Teaching and Education, 1(1), 27-37. https://doi.org/10.22437/ijolte.v1i1.4594

Widodo, U. (2020). Contextual Teaching and Learning: An Alternative Method to Teach Speaking. SELL Journal: Scope of English Language Teaching, Linguistics, and Literature, 5(2), 115-130. http://www.publikasi.stkippgri-bkl.ac.id/index.php/SL/article/download/424/343

Wijarwadi, W. (2008). The Effectiveness of Contextual Teaching and Learning to Teach Speaking.

Yusuf, S. B., Nasir, C., \& Rohiman, C. L. N. (2018). Using think-aloud method in teaching reading skill. Studies in English Language and Education, 5(1), 148-159. https://doi.org/10.24815/siele.v5i1.9898 